\title{
Influence of Ventilation in Healthcare Facilities Prevention of Infection COVID-19: Systematic Review Study
}

\author{
Abdolmajid Fadaei ${ }^{1 *}$ \\ ${ }^{1}$ Shahrekord University of Medical Sciences, IRAN \\ *Corresponding Author: ali2fadae@yahoo.com \\ Citation: Fadaei, A. (2021). Influence of Ventilation in Healthcare Facilities Prevention of Infection COVID-19: Systematic Review Study. \\ European Journal of Sustainable Development Research, 5(4), em0170. https://doi.org/10.21601/ejosdr/11202
}

\section{ARTICLE INFO}

Received: 6 Jun. 2021

Accepted: 15 Aug. 2021

\begin{abstract}
Currently, (2019-2020) COVID-19 global pandemic is caused by a member of the Coronaviridae group. Some human viruses are spread from human to human by way of droplets or aerosols, but fewer viruses are persistently airborne in transmission, and the healthcare-associated epidemic of airborne viral infection are restricted to very few surrogates. In addition, it is one of the most efficient tools (i.e., the second one) for preventing inside air pollution through ventilation. To our aim was to perform a rapid literature review to answer the following question: does ventilation in healthcare facilities prevention of infection COVID-19?

This study is a systematic review by searching among published articles in Embase, PubMed/MEDLINE, Scopus, PubMed Central (PMC), Google Scholar databases as well as medRxiv by using the following keywords: 'COVID19', 'healthcare settings', 'prevention', 'ventilation', 'Hospital, 'Infection', and 'Air changes per hour.

After investigating the information and quality of articles, 52 articles were included in this study. The literature denotes that temperature, relative humidity, and ventilation and air conditioning systems have beneficial effects to prevent COVID-19 infection.

The results of this study demonstrated that many parameters basic strategy of control COVID-19 include: hand hygiene, social distancing, screening and case finding, isolation and separating, decontamination and disinfection, and effective ventilation. Thus, based on recommendations of CDC, WHO, and other studies effective ventilation is the most important transmission of respiratory disease control strategy, specially COVID19.
\end{abstract}

Keywords: coronaviruses infections, prevention and control, ventilation

\section{INTRODUCTION}

Initially, COVID-19 that begun at the end of 2019 has turned into a pandemic. According to the evidence, its main ways of transmission are person-to-person and viral droplets $(>5-10 \mu \mathrm{m}$ in diameter) of infected patients, or sings at short distances, commonly $<1-2 \mathrm{~m}$. However, there are doubts about its transmission through $(<5 \mu \mathrm{m}$ in diameter), remaining infectious when suspended in the air over long distances and time (Chirico et al., 2020). It worth noting that personal hygiene and avoiding infected surfaces is of crucial importance. Ventilation is a principal infectious disease prevention method in health care centers and other facilities, using a suitable HVAC (heating, ventilation, and air conditioning) system could be mitigated virulence of SARSCoV-2.

Currently, indoor air quality (IAQ) has achieved more consideration because people are spending more time at home (70-90\%), the impact of outdoor source on IAQ, and existence of various kinds of pollutants such as total volatile organic compounds (TVOCs), household cleaning products, disinfectant sprays, particulate matter (PM), $\mathrm{CO}_{2}$, and bioaerosols agents in IAQ (Domínguez-Amarillo et al., 2020). There are several parameters, such as origins, building construction and materials, air conditioning and its speed, inhabitant practice and functions that influence the IAQ (Harbizadeh et al., 2019). This systematic review intended to investigate does ventilation in healthcare facilities prevention of infection COVID-19?. The spread of epidemics is associated with air pollutants (carbon monoxide, sulfur oxides, nitrogen oxides, ground-level ozone, particulate matter, and lead, other pollutants (Polycyclic Aromatic Hydrocarbons (PAHs), Volatile Organic Compounds (VOCs), and Dioxins. Global climate change (greenhouse gases, ozone-depleting), and climatological factors (e.g., wind speed, temperature, humidity) (Manisalidis et al. 2020), for example, as the virus has a lipid envelope, its survival is longer in areas with lower $(<50 \%)$ relative humidity $(\mathrm{RH})$ than $\mathrm{RH}>80 \%$. The role of air pollution in the transmission of the COVID-19 virus by 
aerosols is still under discussion. Researches demonstrated that there were more studies related to SARS-COV-2 transmission from hospital air from Asian countries (Iran, China, Singapore) and the highest number of researches was related to China (Aghalari et al., 2021). Many studies had been conducted on the effects from indoor air pollutants in hospitals such as carbon dioxide, carbon monoxide, formaldehyde, fungi and mold (Gola et al., 2019; Slama et al., 2019), but there is few researches on viruses in the hospitals air and role of ventilation. Correia et al. analyzed the ventilation methods and the airborne pathway of SARS-CoV-2 (Correia et al., 2020). Kim et al. also investigated the effects of humidity and other parameters on the formation of a coronavirus aerosol (Kim et al., 2007). Gola et al. investigated the mechanical ventilation in healthcare settings, and their heating, ventilation and air conditioning (HVAC) systems operation (Gola et al., 2020).

There are a few researches on how to prevent airborne COVID-19 transmission. On the other hand, the estimation of the risk of disease related with the use of air-conditioning is necessary for making correct decisions, also ventilation has a crucial role in preventing contagious diseases in healthcare facilities as well as other settings. Therefore, this fast literature review tries to provide adequate knowledge and strategies for ventilation methods and control and prevention strategies.

\section{METHODS}

Following a systematic review design, this research was conducted to evaluate can ventilation in healthcare facilities prevention of infection COVID-19? In this study used of databases of Scopus, ISI, Web of Science, Google Scholar, PubMed (MEDLINE), World Health Organization, and American Centers for Disease Control (CDC) and Prevention using MeSH (Medical Subject Headings) keywords for the period of December 2019 to April 2021. Descriptive statistics is performed categorizing. Hence, using appropriate keywords ("Coronaviruses" OR "CoV” OR "Human Coronaviruses " OR "HCoV” OR "nCov” OR "Novel Coronaviruses " OR "2019 Novel Coronavirus” OR “Covid-19” OR “2019-nCoV” OR "Severe Acute Respiratory Syndrome-Coronaviruses-
2"OR”SARS-COV-2”) AND (“Air pollution” OR “Air pollution “OR”Ventilation” OR “Air changes per hour” OR "healthcare facilities") AND ("Hospital); ("indoor air quality AND COVID19”); ("Prevention Methods" OR "Infection Prevention and Control") the abovementioned databases were searched. Information on the authors' name, type study, study remarks, type of setting, and main variables parameters like temperature, relative humidity, and type of ventilation and outcomes were collected. As shown in Figure 2, a total of 120 peer reviewed publications were accessed based on the relevance of titles to the research. These were further screened to 73 after reading through their abstracts. Following screening the full text of the articles, 52 were used for this review, excluding the Preferred Reporting Items for Systematic Reviews and Meta-Analyses (PRISMA) reference (Moher et al., 2010). There are several methods for measurement of ventilation rate such as: Air changes per hour, volumetric airflow per person, volumetric airflow per floor area, percent outdoor air intake, and $\mathrm{CO}_{2}$ concentration. In this study used to air changes per hour, volumetric airflow per person, percent outdoor air intake, and $\mathrm{CO}_{2}$ concentration methods.

Air changes per hour one significant change relates to the ventilation recommendations for patient rooms, values were estimated as follows: (World Health Organization, 2020b)

$$
t_{2}-t_{1}=-\left[\ln \left(C_{2} / C_{1}\right) /(Q / V)\right] * 60
$$

with $t_{1}=0$, where $t_{1}=$ initial time point in minutes $t_{2}=$ final time point in minutes $C_{1}=$ inlet concentration of contaminant, $C_{2}=$ outlet concentration of contaminant $C_{2} / C_{1}$ $=1-$ (removal efficiency $/ 100) Q=$ air flow rate in cubic feet/hour

$V=$ room volume in cubic feet $Q / V=\mathrm{ACH}$.

In the discussion section, we discussed the most important findings in three parts included: indoor air ventilation, indoor air relative humidity, and indoor air temperature.

\section{RESULTS AND DISCUSSION}

Concentration on 10 articles, 60\% (6), 20\% (2), and 20\% (2) were based on the simulation, experimental, and observational methods, respectively. (Figure 1). These articles were from

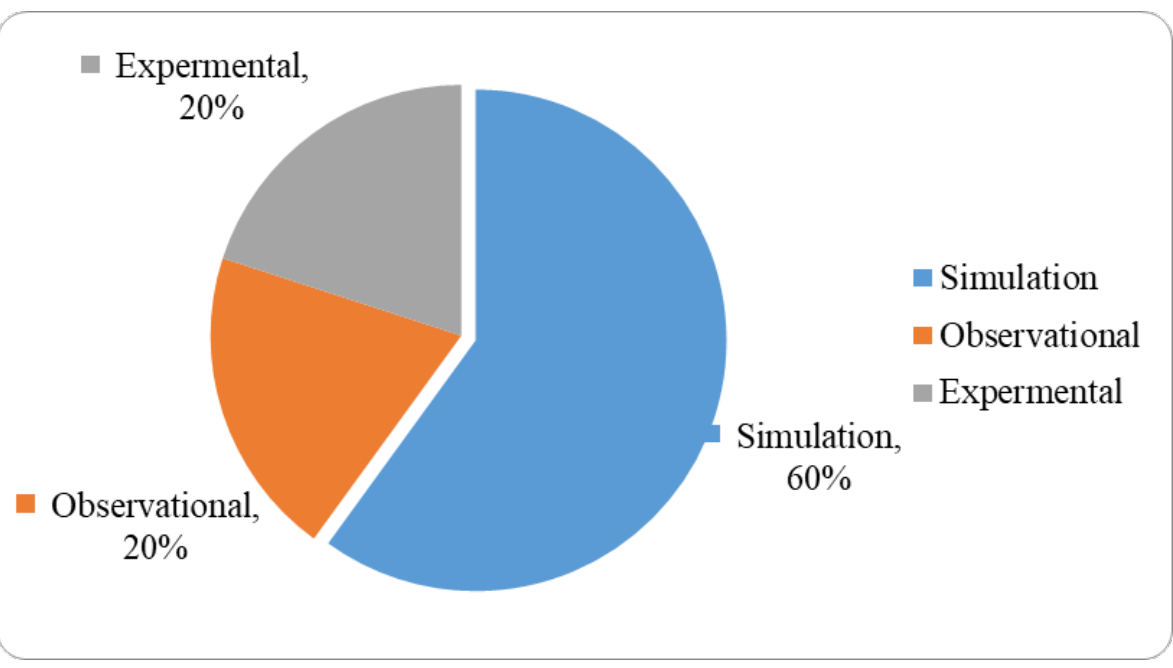

Figure 1. Condition type of design researches 


\begin{tabular}{|c|}
\hline $\begin{array}{l}\text { Google search } \\
\text { Search items: Coronaviruses, } \\
\text { disinfectant, COVID-19, indoor, } \\
\text { ventilation, healthcare, prevention }\end{array}$ \\
\hline $\begin{array}{l}\text { Relevant papers screened from titles, } \\
\mathrm{N}=120\end{array}$ \\
\hline $\begin{array}{l}\text { Papers screened from abstract, papers } \\
\text { excluded at this level, } N=37\end{array}$ \\
\hline$\downarrow$ \\
\hline $\begin{array}{l}\text { Papers included after screening from } \\
\text { abstract level, } N=83\end{array}$ \\
\hline $\begin{array}{l}\text { Papers screened from full text, papers } \\
\text { excluded at this level, } \mathrm{N}=31\end{array}$ \\
\hline 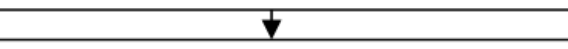 \\
\hline $\begin{array}{l}\text { Papers included in this study after } \\
\text { screening from full text, } N=52\end{array}$ \\
\hline
\end{tabular}

Figure 2. Chart presentation the method of the analysis process health care/hospital (4), public buildings (3), residential places (1), dormitory (1), and offices (1). The main results are provided in Table 3. Based on results this study, two articles mentioned that SARS-COV-2 can be reduced by ventilation in the air hospitals, while eight noted the ventilation effect in closed areas. Demonstrated that Tables 1 and 2 air changes/hour and outline of ventilation according to guidelines and standards of CDC and those published for controlling infection at healthcare settings.

\section{Indoor Air Ventilation}

The results of this study illustrated that there were more researches associated to SARS-COV-2 and ventilation in closed spaces. According to results, two papers mentioned that ventilation was not associated with reduced levels of SARSCOV-2 in the air of hospitals, meanwhile, eight papers reported vice versa. Hence, more studies are needed to investigate whether ventilation systems are associated with declined transmission of SARS-COV-2. In healthcare settings, ventilation strategy and air distribution model affect the transmission of contagious diseases.

There are three methods that may be used to ventilate spaces within health-care settings: natural, mechanical and combination (mixed-mode) ventilation. Any decision on climate to use natural, combination or mechanical ventilation should take into account climate, including prevalent wind path, floor plan, need, availability of resources, and the cost of the ventilation system (World Health Organization, 2020a).

In health-care settings, the ventilation rate (mechanical method) should be 6-12, ideally $12 \mathrm{ACH}$ for new constructions and mean natural ventilation rate is $160 \mathrm{~L} / \mathrm{s} /$ patient, with a recommended negative pressure differential of $\geqslant 2.5 \mathrm{~Pa}$ to

Table 1. Air changes/hour (ACH) and time required for airborne-contaminant removal by efficiency (Chinn and Sehulster, 2003)

\begin{tabular}{ccc}
\hline ACH & Time (mins.) required for removal: 99\% & $\begin{array}{c}\text { Time (mins.) required for removal: 99.9\% } \\
\text { efficiency }\end{array}$ \\
\hline 2 & 138 & 207 \\
\hline 4 & 69 & 104 \\
\hline 6 & 46 & 35 \\
\hline 8 & 28 & 52 \\
\hline 10 & 23 & 41 \\
\hline 12 & 18 & 28 \\
\hline 15 & 14 & \\
\hline 20 & 6 & \\
\hline 50 & \\
\hline
\end{tabular}

Table 2. Outline of ventilation characteristics in chosen areas of health-care centers (Chinn and Sehulster, 2003)

\begin{tabular}{|c|c|c|c|c|c|}
\hline Characteristics & $\begin{array}{l}\text { All room (includes bronchoscopy } \\
\text { suites) }\end{array}$ & Protective environment & $\begin{array}{l}\text { Critical care } \\
\text { room }\end{array}$ & $\begin{array}{c}\text { Isolation } \\
\text { anteroom }\end{array}$ & $\begin{array}{c}\text { Operating } \\
\text { room }\end{array}$ \\
\hline \multicolumn{6}{|c|}{ room } \\
\hline Air pressure & Negative & Positive & $\begin{array}{l}\text { Positive, negative, } \\
\text { or neutral }\end{array}$ & $\begin{array}{c}\text { Positive or } \\
\text { negative }\end{array}$ & Positive \\
\hline Room air changes & $\begin{array}{l}\geqslant 6 \mathrm{ACH} \text { (for existing rooms); } \\
\geqslant 12 \mathrm{ACH} \text { (fore novation or new } \\
\text { construction) }\end{array}$ & $\geqslant 12 \mathrm{ACH}$ & $\geqslant 6 \mathrm{ACH}$ & $\geqslant 10 \mathrm{ACH}$ & $\geqslant 15 \mathrm{ACH}$ \\
\hline Sealed & Yes & Yes & No & Yes & Yes \\
\hline $\begin{array}{l}\text { Filtration } \\
\text { supply }\end{array}$ & 90\% (dust-spot ASHRAE52.1 1992) & $\begin{array}{c}99.97 \% \text { (Fungal spore filter at } \\
\text { point of use (HEPA at } 99.97 \% \text { of } \\
0.3 \mu \text { m particles)) }\end{array}$ & $>90 \%$ & $>90 \%$ & $90 \%$ \\
\hline Recirculation & $\begin{array}{c}\text { No (Recirculated air may be used if } \\
\text { the exhaust air is first processed } \\
\text { through a HEPA filter.) }\end{array}$ & Yes & Yes & No & Yes \\
\hline
\end{tabular}


Table 3. Most important characteristics of reviewed papers

\begin{tabular}{|c|c|c|c|}
\hline Type study & Type setting & Remarks & Reference \\
\hline Simulation & Public buildings & $\begin{array}{l}\text { A minimum RH standard of } 40 \% \text { for populated spaces not only decrease the } \\
\text { effect of the virus, but also can decrease the effect of more viral infections, } \\
\text { both arid and moist places. }\end{array}$ & (Ahlawat et al., 2020) \\
\hline Simulation & Public buildings & $\begin{array}{l}\text { There is a major and firm possibility of airborne spread of COVID-19 in indoor } \\
\text { air ambient }\end{array}$ & (Noorimotlagh et al., 2020) \\
\hline Simulation & Hospitals & Ventilation has a major impact on SARS-CoV-2 spread & (Chen et al., 2011) \\
\hline Experimental & $\begin{array}{l}\text { Residential } \\
\text { Indoor }\end{array}$ & $\begin{array}{l}\text { Action programs should be promoted for the reinstatement or enhancement of } \\
\text { the filtration systems of the air-conditioning and heating systems in houses }\end{array}$ & $\begin{array}{l}\text { (Domínguez-Amarillo et } \\
\text { al., 2020) }\end{array}$ \\
\hline Simulation & Patient Rooms & Increase ventilation rates were not causes reduce aerosol concentrations & $\begin{array}{l}\text { (Mousavi and Grosskopf, } \\
\text { 2015) }\end{array}$ \\
\hline Experimental & Hospitals & $\begin{array}{r}\text { The few COVID-19 studies did not provide adeq } \\
\text { may be spread by HVAC } \mathrm{s}\end{array}$ & (Chirico et al., 2020) \\
\hline Observational & Dormitory & $\begin{array}{c}\mathrm{CO}_{2} \text { mean level was } 1230 \pm 408 \mathrm{ppm} \\
\text { and } 1492 \pm 837 \mathrm{ppm} \text { in the two dormitory buildings. }\end{array}$ & (Zhu et al., 2020) \\
\hline Simulation & Public buildings & $\begin{array}{l}\text { Use of engineering controls in populated spaces such as: separating infected } \\
\text { individuals, opening windows and doors, and using moveable air-cleaning } \\
\text { devices when practicable }\end{array}$ & (Morawska et al., 2020) \\
\hline Observational & $\begin{array}{c}\text { Health care } \\
\text { centers }\end{array}$ & $\begin{array}{l}\text { Simple changes in hospital structure noticeably enhanced natural ventilation, } \\
\text { and seriously decreased air borne infection risk at little cost }\end{array}$ & (Escombe et al., 2019) \\
\hline Simulation & Offices & $\begin{array}{l}\text { Relationship among air conditioning and sick building syndrome (SBS) signs in } \\
\text { various rooms, where higher ventilation rates, up to about } 25 \mathrm{l} / \mathrm{s} \text { per capita, are } \\
\text { related with decreased symptoms }\end{array}$ & (Sundell et al., 2011) \\
\hline
\end{tabular}

gurantee air flows from the corridor into the rooms designed for hospitalizing patients (Feng et al., 2020; World Health Organization 2020b). Ventilation (>6 ACH) can guarantee both negative pressure difference $(>2.5 \mathrm{~Pa})$ and airflow difference (> $56 \mathrm{~L} / \mathrm{s}$ ) (Table 1) (Control and Prevention; Jayaweera et al. 2020). Upgrading ventilation of health care centers will dilution and removal potentially infectious aerosols (Somsen et al., 2020).

The maximum ventilation rates in liter per second per person $(\mathrm{l} / \mathrm{s} / \mathrm{p})$ of 5 and air exchange velocity of $0.04 \mathrm{~m} / \mathrm{s}$ in most school buildings, restaurants and offices (Amoatey et al., 2020).

Inappropriate use of ventilation systems has severe negative effects on transmission of COVID-19 (Correia et al., 2020). Effective ventilation is a major technique to prevent expansion of contagious disease, improved ventilation may be a key factor in prevention the spread of the SARS-CoV-2 virus (Gola et al., 2020). One study showed that good mechanical room ventilation using outdoor air would have an effect similar to a 50-60\% vaccination coverage in a poor ventilation system (Spena et al., 2020).

One research demonstrated that the majority of COVID-19 patients infected at home became infected in a cold, air conditioned, arid, and bad-ventilated indoor condition. Masoumbeigi and colleagues mentioned that mechanical air conditioning and natural ventilation are available methods that can be used for air cleaning in hospitals (Masoumbeigi et al., 2020). Masoumbeigi and colleagues and Faridi and colleagues illustrated that ventilation (either mechanical or natural) were applied in healthcare facilities (Faridi et al., 2020; Masoumbeigi et al., 2020). In a study by Salonen et al. (2014) ventilation air conditioning system is principal to maintain negative pressure within separation rooms, to protect the health of staff, patients and visitors, as well as to control patients' risk for airborne diseases (Salonen et al., 2013). One study reported that Indoor aerosol levels are strongly dependent on the availability and operation of ventilation and filtering installations (Dobricic et al., 2020). In a study by Ahlawat et al. (2020) the transmission pathways of SARS-CoV-2 are still discussed, but recent evidence strongly proposes that COVID-19 could be transmitted via air in places poor ventilation (Ahlawat et al., 2020). One study showed that appropriate ventilation and the use of separate ventilation devices for SARS-COV-2 patients were introduced as effective systems to prevent the SARS-COV-2 transmission (Liu et al., 2020). In a study by Chirico et al. (2020) the studies available to date are not sufficient to support the conclusion that airconditioning systems help the spread of the SARS-CoV-2 infection in office and indoor places (Chirico et al., 2020).

Another study by Li and colleagues, various health care center wards were prepared using heating, ventilation and air conditioning (HVAC) systems (Li et al., 2020). A research reported no strong evidence to support the association between COVID-19 air-bore transmission and HVAC systems (Belingheri et al., 2020). Wells-Riley equation contains the major contribution of ventilation:

$$
P=\frac{n I}{n S}=1-\exp \left(-\frac{q \Gamma t s}{Q}\right)
$$

where $n I$ is the expected frequency of patients at room, $n S$ is the frequency of susceptible at room at $t s, n E$ is the number of spreaders 'quanta' (to the mean viral load necessary for infection transmission) at a rate $\gamma i$ (giving the total emission rate $\left.\Gamma=\sum_{i=1}^{n E} \gamma i\right), q$ is the time-average volume flux of exhaled air per person and $Q$ is the volume flux of fresh (clean) air entering the room (Bhagat et al., 2020).

\section{Indoor Air Relative humidity (RH)}

According to the evidence, in health care centers, $\mathrm{RH}$ is a major contribution for preventing contagious diseases, as it affects both growth and transfer of airborne of contagious agents (Azuma et al., 2020; Fadaei, 2014). RH affects the transmission of contagious agents. Suitable RH affects the survivability of: Viruses with lipid envelops (i.e., Influenza 
virus, Para-Influenza virus, Corona virus, and Varicella zoster virus lower RH (20\%-30\%RH); (b) Viruses non-lipid enveloped (i.e. Adenovirus, Enterovirus, and Rhinoviruses higher RH70\%90\% RH); (c) Gram-negative bacteria(i.e. Serratia marcescens, Klebsiella, and Proteus vulgaris lower RH (<50\% RH): and (d) Airborne gram-positive(i.e. Staphylococcus epidermidis, Streptococcus haemolyticus, Bacillus subtilis, and Streptococcus pneumonia bacteria lower RH (<50\% RH) (Ahmadi and Fadaei, 2021; Shajahan et al., 2019). Nevertheless, it's well-proved that low RH (<20\%) affects susceptibility to various contagious agents (Dietz et al., 2019). On the other hand, the low RH negatively affects the ability of the immune system's to cope with microorganisms (Ahlawat et al., 2020). Another study by Ahlawat reported that close areas with in dry conditions (humidity (< 40\%), there is high probability of COVID-19 transmission(Ahlawat et al. 2020). Another study suggested an RH of 30-60\% for healthcare settings (Balaras et al., 2007). One study reported a negative association between RH (increased from 23.33 to $82.67 \%$ ) and COVID-19 transmission (Yao et al., 2020). Biktasheva mentioned that humidity affects COVID-19 transmission (Biktasheva, 2020). Another study by Huang et al., reported, in conditions with low indoor temperature and high environment temperature, there is a correlation between $\mathrm{RH}$ and outdoor absolute humidity $(\mathrm{AH})$, which translates into increased COVID-19 transmission (Huang et al., 2020). One study explained that the viruses survived well at RHs below $33 \%$ and at $100 \%$, whereas, at the intermediate RHs the viability was noticeably reduced (Lin and Marr, 2019). therefore, it is very important to set a minimum relative humidity standard for indoor places such as hospitals, offices, clinics, health care settings, populated areas, restaurants, and public transports for minimization of airborne spread of COVID-19.

\section{Indoor Air Temperature}

It has a crucial impact on patients' perception from thermal comfort. In other words, uncomfortable temperatures negatively affect the patients' satisfaction, like wakefulness and nervousness, and may result in shaking, inattention, and muscular and joint constriction (Shajahan et al., 2019).

Several studies reported creating thermal zones to met various needs of infected cases, and their separate thermal preferences such as: Operating room $24-26^{\circ} \mathrm{C}\left(74.2-78.8^{\circ} \mathrm{F}\right)$, Delivery room $\geqslant 26^{\circ} \mathrm{C}\left(78.8^{\circ} \mathrm{F}\right)$, Nursery (for infants), around $28^{\circ} \mathrm{C} \quad\left(82.4^{\circ} \mathrm{F}\right)$, Patient room $21-24^{\circ} \mathrm{C} \quad\left(70-75^{\circ} \mathrm{F}\right)$, and Bronchoscopy $20-23^{\circ} \mathrm{C}\left(68-73^{\circ} \mathrm{F}\right)$ (Lyon and Freer, 2011). At first days of COVID-19 emergence, the severity of the disease was higher in countries with relatively lower environmental temperature (Hassan et al., 2020). One research explained that a considerable negative relationship among temperature and outbreak (Hassan et al., 2020).

Thus, based on recommends of CDC, WHO, and other studies effective ventilation is of crucial importance for control strategies developed for transmission of respiratory diseases, specially COVID-19 (Chinn and Sehulster, 2003; Fadaei, 2021; Wold Health Organization, 2020b). There are many researches about temperature and humidity such as: temperature should range from 17 to $28^{\circ} \mathrm{C}$, and the $\mathrm{RH}$ should be 40 to $70 \%$ (Guo et al., 2020), the best humidity should range from 40 to $60 \%$ at workplace and a general indoor temperature of $21-23^{\circ} \mathrm{C}$ (Guo et al., 2020). In a study by Turki et al. (2021) in the optimum indoor meteorological status such as temperature $23^{\circ} \mathrm{C}$, relative humidity $53 \%$, without sunlight, the aerosolized SARS-CoV-2 may stay infectious for up to $16 \mathrm{~h}$ (Habeebullah et al., 2021). Some studies say that COVID-19 deactivation is best at around $50-80^{\circ} \mathrm{C}$ and $40-50 \%$ relative humidity (Rezaei et al., 2020). All of these relevant research agrees with the results of the current study.

\section{CONCLUSION}

There is well-established evidence to propose that the temperature, relative humidity, and ventilation and air conditioning systems (ACSs), have beneficial effects to prevent COVID-19 infection. Caution should be taken when setting temperature and relative humidity, using a step-bystep process. The findings propose greatly that rather than natural ventilation (e.g., windows), use of artificial ventilation and ACSs may cause better IAQ in health-care centers and close places and reducing bioaerosols and PM exposure in the indoor air of health-care centers and close places.

Researchers, health decision-makers, policy-makers, to reduce the risk of vulnerability of people to future epidemics and pandemics, can act on six factors basic strategy of control COVID-19 include: hand hygiene, social distancing, screening and case finding, isolation and separating, decontamination and disinfection, and effective ventilation. Items aforementioned will more protect healthcare staffs, patients and the general popular. Our Results confirm that improving ventilation of populated places and hospitals will dilute and get out potentially infectious aerosols. More study and investigation are necessary to investigate the role of outdoor and indoor air quality management, particularly ventilation. Hence, to find whether ventilation systems can decline the spread of COVID-19, which requires more extensive research.

Funding: No external funding is received for this article.

Declaration of interest: The author declares no competing interests.

Ethics approval and consent to participate: Not applicable.

Availability of data and materials: All data generated or analyzed during this study are available for sharing when appropriate request is directed to the author.

\section{REFERENCES}

Aghalari, Z., Dahms, H.-U., Sosa-Hernandez, J. E., OyervidesMuñoz, M. A. and Parra-Saldívar, R. (2021). Evaluation of SARS-COV-2 transmission through indoor air in hospitals and prevention methods: A systematic review. Environmental Research, 110841. https://doi.org/ 10.1016/j.envres.2021.110841

Ahlawat, A., Wiedensohler, A. and Mishra, S. K. (2020). An overview on the role of relative humidity in airborne transmission of SARS-CoV-2 in indoor environments. Aerosol and Air Quality Research, 20(9), 1856-1861. https://doi.org/10.4209/aaqr.2020.06.0302 
Ahmadi, D. and Fadaei, A. (2021). Efficiency evaluation of hospitals sterilization by biological and chemical methods. Quality of Life, 20(1-2), 23-30. https://doi.org/ 10.7251/QOL2101023A

Amoatey, P., Omidvarborna, H., Baawain, M. S. and AlMamun, A. (2020). Impact of building ventilation systems and habitual indoor incense burning on SARS-CoV-2 virus transmissions in Middle Eastern countries. Science of the Total Environment, 733, 139356. https://doi.org/ 10.1016/j.scitotenv.2020.139356

Azuma, K., Yanagi, U., Kagi, N., Kim, H., Ogata, M. and Hayashi, M. (2020). Environmental factors involved in SARS-CoV-2 transmission: effect and role of indoor environmental quality in the strategy for COVID-19 infection control. Environmental Health and Preventive Medicine, 25(1), 1-16. https://doi.org/10.1186/s12199-02000904-2

Balaras, C. A., Gaglia, A. G., Georgopoulou, E., Mirasgedis, S., Sarafidis, Y. and Lalas, D. P. (2007). European residential buildings and empirical assessment of the Hellenic building stock, energy consumption, emissions and potential energy savings. Building and Environment, 42(3), 1298-1314. https://doi.org/10.1016/j.buildenv.2005.11.001

Belingheri, M., Paladino, M. E. and Riva, M. A. (2020). COVID19: health prevention and control in non-healthcare settings. Oxford University Press UK. https://doi.org/10.1093/ occmed/kqaa048

Bhagat, R. K., Wykes, M. D., Dalziel, S. B. and Linden, P. (2020). Effects of ventilation on the indoor spread of COVID-19. Journal of Fluid Mechanics, 903, F1. https://doi.org/10.1017/jfm.2020.720

Biktasheva, I. V. (2020). Role of a habitat's air humidity in Covid-19 mortality. Science of the Total Environment, 736, 138763. https://doi.org/10.1016/j.scitotenv.2020.138763

Chen, C., Zhao, B., Yang, X. and Li, Y. (2011) Role of two-way airflow owing to temperature difference in severe acute respiratory syndrome transmission: revisiting the largest nosocomial severe acute respiratory syndrome outbreak in Hong Kong. Journal of the Royal Society Interface 8(58), 699710. https://doi.org/10.1111/j.1600-0668.2004.00317.x

Chinn, R. Y. and Sehulster, L. (2003). Guidelines for environmental infection control in health-care facilities; recommendations of $C D C$ and Healthcare Infection Control Practices Advisory Committee (HICPAC). https://www.cdc.gov/infectioncontrol/guidelines/environ mental/index.html

Chirico, F., Sacco, A., Bragazzi, N. L. and Magnavita, N. (2020). Can air-conditioning systems contribute to the spread of SARS/MERS/COVID-19 infection? Insights from a rapid review of the literature. International Journal of Environmental Research and Public Health, 17(17), 6052. https://doi.org/10.3390/ijerph17176052

Control CFD, Prevention Scientific brief: SARS-CoV-2 and potential airborne transmission. 2020.
Correia, G., Rodrigues, L., Silva, M. and Gonçalves, T. (2020). Airborne route and bad use of ventilation systems as nonnegligible factors in SARS-CoV-2 transmission. Medical Hypotheses, 109781. https://doi.org/10.1016/j.mehy.2020. 109781

Dietz, L., Horve, P., Coil, D., Fretz, M., Eisen, J. and Van Den Wymelenberg, K. (2019). Novel coronavirus (COVID-19) pandemic: built environment considerations to reduce transmission. mSystems, 5, e00245-20. https://doi.org/ 10.1128/mSystems.00245-20

Dobricic, S., Pisoni, E., Pozzoli, L., Van Dingenen, R., Lettieri, T., Wilson, J. and Vignati, E. (2020). Do environmental factors such as weather conditions and air pollution influence COVID-19 outbreaks, EUR 30376 EN, Publications Office of the European Union, Luxembourg.

Domínguez-Amarillo, S., Fernández-Agüera, J., CesterosGarcía, S. and González-Lezcano, R. A. (2020). Bad air can also kill: residential indoor air quality and pollutant exposure risk during the COVID-19 crisis. International Journal of Environmental Research and Public Health, 17(19), 7183. https://doi.org/10.3390/ijerph17197183

Escombe, A. R., Ticona, E., Chávez-Pérez, V., Espinoza, M. and Moore, D. A. (2019). Improving natural ventilation in hospital waiting and consulting rooms to reduce nosocomial tuberculosis transmission risk in a low resource setting. BMC Infectious Diseases, 19(1), 1-7. https://doi.org/10.3390/ijerph18105120

Fadaei, A. (2014). Comparison of environmental health indices of private clinics in Chramahal and Bakhtiari province, Iran. Advances in Environmental Biology, 8(7), 2335-2338.

Fadaei, A. (2021). Ventilation systems and COVID-19 spread: Evidence from a systematic review study. European Journal of Sustainable Development Research, 5(2), em0158. https://doi.org/10.21601/ejosdr/10845

Faridi, S., Niazi, S., Sadeghi, K., Naddafi, K., et al. (2020). A field indoor air measurement of SARS-CoV-2 in the patient rooms of the largest hospital in Iran. Science of the Total Environment, 725, 138401. https://doi.org/10.1016/ j.scitotenv.2020.138401

Feng, Y., Marchal, T., Sperry, T. and Yi, H. (2020). Influence of wind and relative humidity on the social distancing effectiveness to prevent COVID-19 airborne transmission: A numerical study. Journal of Aerosol Science, 105585. https://doi.org/10.1016/j.jaerosci.2020.105585

Gola, M., Caggiano, G., De Giglio, O., Napoli, C., et al. (2020). SARS-CoV-2 indoor contamination: Considerations on anti-COVID-19 management of ventilation systems, and finishing materials in healthcare facilities. Annali di Igiene: Medicina Preventiva e di Comunità, 33(4), 381-392. https://doi.org/10.7416/ai.2020.2396

Gola, M., Settimo, G. and Capolongo, S. (2019). Indoor air quality in inpatient environments: a systematic review on factors that influence chemical pollution in inpatient wards. Journal of Healthcare Engineering, 2019, 8358306. https://doi.org/10.1155/2019/8358306 
Guo, M., Xu, P., Xiao, T., He, R., Dai, M. and Zhang, Y. (2020). Review and comparison of HVAC operation guidelines in different countries during the COVID-19 pandemic. Building and Environment, 187, 107368. https://doi.org/10.1016/j.buildenv.2020.107368

Habeebullah, T. M., Abd El-Rahim, I. H. and Morsy, E. A. (2021). Impact of outdoor and indoor meteorological conditions on the COVID-19 transmission in the western region of Saudi Arabia. Journal of Environmental Management, 288, 112392. https://doi.org/10.1016/ j.jenvman.2021.112392

Harbizadeh, A., Mirzaee, S. A., Khosravi, A. D., Shoushtari, F. S., et al. (2019). Indoor and outdoor airborne bacterial air quality in day-care centers (DCCs) in greater Ahvaz, Iran. Atmospheric Environment, 216, 116927. https://doi.org/10.1016/j.atmosenv.2019.116927

Hassan, M. M., El Zowalaty, M. E., Khan, S. A., Islam, A., Nayem, M. R. K. and Järhult, J. D. (2020). Role of environmental temperature on the attack rate and case fatality rate of Coronavirus Disease 2019 (COVID-19) Pandemic. Infection Ecology \& Epidemiology, 10(1), 1792620. https://doi.org/10.1080/20008686.2020.1792620

Huang, Z., Huang, J., Gu, Q., Du, P., Liang, H. and Dong, Q. (2020). Optimal temperature zone for the dispersal of COVID-19. Science of The Total Environment, 736, 139487. https://doi.org/10.1016/j.scitotenv.2020.139487

Jayaweera, M., Perera, H., Gunawardana, B. and Manatunge, J. (2020). Transmission of COVID-19 virus by droplets and aerosols: A critical review on the unresolved dichotomy. Environmental Research, 188, 109819. https://doi.org/10.1016/j.envres.2020.109819

Kim, S. W., Ramakrishnan, M., Raynor, P. C. and Goyal, S. M. (2007). Effects of humidity and other factors on the generation and sampling of a coronavirus aerosol. Aerobiologia, 23(4), 239-248. https://doi.org/10.1007/ s10453-007-9068-9

Li, Y., Fan, Y., Jiang, L. and Wang, H. (2020). Aerosol and environmental surface monitoring for SARS-CoV-2 RNA in a designated hospital for severe COVID-19 patients. Epidemiology \& Infection, 148, E154. https://doi.org/10.1017/S0950268820001570

Lin, K. and Marr, L. C. (2019). Humidity-dependent decay of viruses, but not bacteria, in aerosols and droplets follows disinfection kinetics. Environmental Science \& Technology, 54(2), 1024-1032. https://doi.org/10.1021/acs.est.9b04959

Liu, Y., Ning, Z., Bhen, Y., Guo, M., et al. (2020) Aerodynamic analysis of SARS-CoV-2 in two Wuhan hospitals. Nature, 582(7813), 557-560. https://doi.org/10.1038/s41586-0202271-3

Lyon, A. and Freer, Y. (2011). Goals and options in keeping preterm babies warm. Archives of Disease in Childhood-Fetal and Neonatal Edition, 96(1), F71-F74. https://doi.org/10.1136/adc.2009.161158

Manisalidis, I., Stavropoulou, E., Stavropoulos, A. and Bezirtzoglou, E. (2020). Environmental and health impacts of air pollution: A review. Frontiers in Public Health, 8, 14. https://doi.org/10.3389/fpubh.2020.00014
Masoumbeigi, H., Ghanizadeh, G., Arfaei, R. Y., Heydari, S., et al. (2020). Investigation of hospital indoor air quality for the presence of SARS-Cov-2. Journal of Environmental Health Science and Engineering, 18(2), 1259-1263. https://doi.org/10.1007/s40201-020-00543-3

Moher, D., Liberati, A., Tetzlaff, J. and Altman, D. G. (2010). Preferred reporting items for systematic reviews and metaanalyses: the PRISMA statement. International Journal of Surgery, 8(5), 336-341. https://doi.org/10.1136/bmj.b2535

Morawska, L., Tang, J. W., Bahnfleth, W., Bluyssen, P. M., et al. (2020). How can airborne transmission of COVID-19 indoors be minimised? Environment International, 142, 105832. https://doi.org/10.1016/j.envint.2020.105832

Mousavi, E. S. and Grosskopf, K. R. (2015). Ventilation rates and airflow pathways in patient rooms: A case study of bioaerosol containment and removal. Annals of Occupational Hygiene 59(9), 1190-1199. https://doi.org/10.1093/annhyg/mev048

Noorimotlagh, Z., Jaafarzadeh, N., Martínez, S. S. and Mirzaee, S. A. (2020). A systematic review of possible airborne transmission of the COVID-19 virus (SARS-CoV-2) in the indoor air environment. Environmental Research, 193, 110612. https://doi.org/10.1016/j.envres.2020.110612

Worl Health Organization. (2020a). Infection prevention and control during health care when COVID-19 is suspected: interim guidance, 19 March 2020. World Health Organization.

https://apps.who.int/iris/handle/10665/331495

Worl Health Organization. (2020b). Infection prevention and control during health care when novel coronavirus ( $\mathrm{nCoV}$ ) infection is suspected: interim guidance, 25 January 2020. http://apps.who.int/iris/10665/112656

Rezaei, N., Jafari, M., Nazari, A., Salehi, S., et al. (2020) A novel methodology and new concept of SARS-CoV-2 elimination in heating and ventilating air conditioning systems using waste heat recovery. AIP Advances, 10(8), 085308. https://doi.org/10.1063/5.0021575

Salonen, H., Lahtinen, M., Lappalainen, S., Nevala, N., et al. (2013). Physical characteristics of the indoor environment that affect health and wellbeing in healthcare facilities: A review. Intelligent Buildings International 5(1), 3-25. https://doi.org/10.1080/17508975.2013.764838

Shajahan, A., Culp, C. H. and Williamson, B. (2019). Effects of indoor environmental parameters related to building heating, ventilation, and air conditioning systems on patients' medical outcomes: A review of scientific research on hospital buildings. Indoor Air, 29(2), 161-176. https://doi.org/10.1111/ina.12531

Slama, A., Śliwczyński, A., Woźnica, J., Zdrolik, M., et al. (2019). Correction to: Impact of air pollution on hospital admissions with a focus on respiratory diseases: a timeseries multi-city analysis. Environmental Science and Pollution Research, 27(17), 22139.

Somsen, G. A., van Rijn, C., Kooij, S., Bem, R. A. and Bonn, D. (2020). Small droplet aerosols in poorly ventilated spaces and SARS-CoV-2 transmission. The Lancet Respiratory Medicine, 8(7), 658-659. https://doi.org/10.1016/S22132600(20)30245-9 
Spena, A., Palombi, L., Corcione, M., Carestia, M. and Spena, V. A. (2020). On the optimal indoor air conditions for SARS-CoV-2 inactivation. An enthalpy-based approach. International Journal of Environmental Research and Public Health, 17(17), 6083. https://doi.org/10.3390/ ijerph17176083

Sundell, J., Levin, H., Nazaroff, W. W., Cain, W. S., et al. (2011). Ventilation rates and health: multidisciplinary review of the scientific literature. Indoor Air, 21(3), 191-204. https://doi.org/10.1111/j.1600-0668.2010.00703.x
Yao, M., Zhang, L., Ma, J. and Zhou, L. (2020). On airborne transmission and control of SARS-Cov-2. Science of The Total Environment 139178. https://doi.org/10.1016/j.scitotenv.2020.139178

Zhu, S., Jenkins, S., Addo, K., Heidarinejad, M., et al. (2020). Ventilation and laboratory confirmed acute respiratory infection (ARI) rates in college residence halls in College Park, Maryland. Environment International, 137, 105537. https://doi.org/10.1016/j.envint.2020.105537 